\title{
Selected Reference Books of 1965-66
}

\section{INTRODUCTION}

This ARTICLE continues the semi-annual series ${ }^{1}$ originally edited by Constance M. Winchell. Though it appears under a byline the list is actually a project of the reference department of the Columbia University Libraries, and notes are signed with the initials of the individual staff members. ${ }^{2}$

Since the purpose of the list is to present a selection of recent scholarly and foreign works of interest to reference workers in university libraries it does not pretend to be either well balanced or comprehensive. Code numbers (such as A11, 1A26, 2S22) have been used to refer to titles in the Guide ${ }^{3}$ and its supplements.

\section{GuIDES}

Totok, Wilhelm, Weitzel, Rolf, and Weimann, Karl-Heinz. Handbuch der bibliographischen Nachschlagwerke. 3. erweiterte, völlig neu bearb. Aufl. Frankfurt am Main: V. Klostermann, [1966 . 362p. DM 45.

The new Handbuch represents a complete revision and updating (to late 1965) of the 1958 edition (Suppl. 4A80). It remains a fairly selective, annotated bibliography of bibliographies (with some other closely related types of reference works included) concentrating on publications of Europe and the United States. While organization of this edition is basically that of the previous one, there are changes within certain sections (e.g., language and

\footnotetext{
${ }^{1}$ CRL, January and July issues starting January 1952.

${ }^{2}$ Linda Benson, Marilyn Goldstein, Rita Keckeissen, Evelyn Lauer, Hugh Macdonald, Barbara Railo, Sarah Ropes, Charlotte Smith.

Constance M. Winchell, Guide to Reference Books (7th ed.; Chicago: ALA, 1951); Supplement (Chicago: ALA, 1954); Second Supplement (Chicago: ALA, 1956); Third Supplement (Chicago: ALA, 1960); Fourth Supplement (Chicago: ALA, 1963).
}

literature). The selection of individual items has obviously undergone thorough review: some entries have been dropped, others from the second edition are subsumed in the annotations, and there are, of course, many new entries.-E.S.

Walford, Albert John. Guide to Reference Material. $2 \mathrm{~d}$ ed. London: Library Association, 1966- . v.1- . (Distr. in U.S. by Bowker)

Contents: v.1, Science and technology. Asst. eds., K. R. Rider and F. R. Taylor. 483p. \&5; \$15.

Approximately three thousand entries in the whole range of science and technology (UDC classes 5/6), plus references in the annotations to another one thousand items, are included in the first volume of the new Walford Guide. (Volume 2 is to deal with social and historical sciences, philosophy and religion; volume 3 with generalia, language and literature, and the arts.) As before, scope is international, with emphasis on British publications. It is an impressive compilation, treating as it does of many works in very specific areas of the pure and applied sciences, as well as the more general reference works in these fields. Not only has a vast number of new items been added, but reference is regularly made in the annotations to superseded works or to works of secondary importance, so that only a very few items from the earlier edition have been dropped altogether. Annotations are generally admirable, some are quite detailed, and in some instances citations to reviews are given. Finally, indexing in this edition appears to be much improved.-E.S.

\section{Library Catalogs}

U.S. National Agricultural Library. National Agricultural Library Catalog. v.1, no.1- , Jan. 1966- . New York: Rowman \& Littlefield, 1966- . Monthly with quarterly cumulations. $\$ 72 \mathrm{yr}$. 
U.S. National Library of Medicine. Current Catalog. Jan. 1/14, 1966- . Washington: U.S. Dept. of Health, Education and Welfare, Public Health Service, 1966-

Biweekly with quarterly cumulations. $\$ 15$ yr.; 4th quarterly cumulation available separately, $\$ 4.50$.

These new publications represent efforts on the part of two of our national libraries to keep scientists, specialists, and librarians informed of new additions to their collections. Their scope and method of publication invite comparison.

Planned as a supplement to the Dictionary Catalog of the library (which is scheduled for publication in early 1967), the National Agricultural Library Catalog reproduces cards for all titles added during the preceding month. It does not, of course, supplant the Bibliography of Agriculture (Guide P233). Monthly issues are in three sections: a subject list under fifteen broad subject categories; an alphabetical main entry listing which cumulates quarterly; and a list of translated articles cataloged for the collection. Plans are being made to publish annual and quinquennial volumes, the latter to serve as permanent supplements to the Dictionary Catalog.

A computer produced publication, the National Library of Medicine Current Catalog supersedes the library's previous Catalog (Suppl. 2P60). Biweekly issues include complete catalog information for works added having an imprint date of the current or two preceding years; cumulations (each of which cumulates all entries from January to date of publication) include all titles added during the period, regardless of imprint date, excepting pre-1801 and Americana items. Main, added, and title entries are interfiled in the biweekly issues; a separate subject section is added in the quarterly cumulations. As many as three appendixes appear in each biweekly issue: a directory of publishers, a record of volumes added to previously cataloged sets, and (less frequently) a list of reprints already in the Library.-E.S.

\section{ENCYCLOPEDIA}

Grote Winkler Prins encyclopedie in twintig delen. [7. geheel nieuwe druk] Hoofred- actie: J. F. Staal [et al.]; Amsterdam: Elsevier, 1966- . v.1- . $\$ 13.80$ per v. (subscr.)

Contents: v.1, A-Amor.

To judge from the first published volume, the latest edition of this standard Dutch encyclopedia is being entirely revised: many articles have been added, some deleted, and the others rewritten. Among the new subjects are technical or specialized terms in many fields, geographical locations, and biographies of notable people both living and dead. The many illustrations are almost all new, maps and charts have been redrawn, and photographs have been brought up to date. As in the past, many articles are signed, and some have bibliographies, the latter being up to date as of 1965 in this first volume. The twentieth and final volume, scheduled for completion in 1970, will contain an index.S.R.

\section{Newspapers \& Periodicals}

The New York Times Index . . 1863-1874. New York: Bowker, [1966]. 1052p. $\$ 44.50$. (Prior series, v.2)

This is the first volume to be published in the new "Prior series" which is designed to provide index coverage in book form from 1851 to 1912 . The volume is reproduced from existing indexes, originally printed for staff use (and previously available on microfilm), covering periods of three months to a year; they have not been cumulated. While dates of coverage are clearly marked at the top of each page, colored sheets of heavy stock between the years would have facilitated use.-E.S.

The Wellesley Index to Victorian Periodicals, 1824-1900. Walter E. Houghton, ed. [Toronto ${ }_{\text {] }}$ : Univ. of Toronto Pr.;

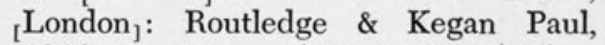
[1966- ]. v.1- . (v.1, 1194p. \$75)

Sub-title: Tables of contents and identification of contributors with bibliographies of their articles and stories.

Scholars in many fields have long awaited publication of this index. Planned as a "multi-volumed work that would provide students of the age with a new and better subject index, a book review index, and an 
author index" (Introd.) to magazines of the period, the completed project will provide more detailed and, in some respects, broader coverage than Poole's Index and the Nineteenth Century Reader's Guide. Work was begun with the author part as the most badly needed, and this first published volume deals with eight major periodicals: Blackwood's, Contemporary Review, Cornhill, Edinburgh Review, Home and Foreign Review, Macmillan's Magazine, North British Review, and Quarterly Review. The next volume, to be published in several years' time, will index another thirty journals.

The first volume alone is a monument of careful research and editing. Part A offers issue-by-issue tables of contents of the magazines, with identification of the contributors (since most articles were published anonymously) and references to the evidence for attribution. Bracketed information is frequently provided to identify the subject of an article, the book under review, etc., and citations are given to reprintings of individual articles. Poetry is omitted. Part B, "Bibliographies of Contributors," furnishes an author approach, listing the articles of each contributor and referring to item number in Part A for the full citation. An index of initials and pseudonyms is also included.-E.S.

\section{PHILOSOPHY}

International Directory of Philosophy and Philosophers. Gilbert Varet and Paul Kurtz, eds. New York, Humanities Pr., [1966]. 235p. \$10.

"Published under the auspices of the International Institute of Philosophy, with the aid of UNESCO."- t.p.

With the purpose of providing a directory "to serve as a guide to philosophy on a world-wide basis" (Pref.) the editors have assembled information on philosophical societies and organizations, institutions of higher learning and philosophical research, and philosophical publications. The directory is in two sections: Part I is a detailed list of philosophical organizations which are primarily international in character, and entries include a brief history and chief activities of the organization. Part II is arranged by country or region, and usually includes an introduction, a list of colleges and universities (with names of members of the philosophy faculties), institutes and research centers, philosophical associations and societies, philosophical journals, and publishers who specialize in philosophical works. The introductions (several pages in length for some countries, but not included at all for many others) are good survey essays on the history and character of philosophy in the various regions. Introductions are in English or French; other notes are in English, French, German, or Spanish.-C.S.

\section{ReLigion}

Bible. English. Modern versions. The Jerusalem Bible. Alexander Jones, gen.ed. Garden City, N.Y.: Doubleday, 1966. 1547,498 p. maps. $\$ 16.95$.

Of the many recent editions of the Bible, this work is probably best qualified to join the Oxford Annotated Bible as a scholarly one-volume reference work. It is a very readable version in a well-printed edition with numerous footnotes, marginal references, and introductory notes or essays on individual books or groups of books. It derives from the French version edited at the Dominican École Biblique de Jerusalem under the general editorship of Roland de Vaux, O.P., and known as "La Bible de Jerusalem" (1v. ed., Paris, Éditions du Cerf, 1956). The introductions and notes are "a direct translation from the French, though revised and brought up to date in some places-account being taken of the decisions and general implications of the Second Vatican Council." (Editor's Foreword) The translation of the biblical text, however, goes back to the original languages.E.S.

\section{FOLKLORE}

Russkii folklor; bibliograficheskii ukazatel, 1917/1944. Leningrad: 1966. 682. 1r., $60 \mathrm{k}$.

At head of title: Akademiia nauk SSSR. Institut russkoi literatury.

Although published five years later than the volume covering the years 1945-59 (Suppl. 4K50), this volume is chronologically the first of a bibliographic series on Russian folklore which will be continued 
by occasional supplements. The bibliography provides citations to monographic and periodical materials, newspaper articles, and items in anthologies which were published in the Soviet Union in Russian. This volume includes 5,140 entries in three main sections: (1) texts; (2) research studies, articles, and sketches; (3) educational and methodological literature, including bibliographic surveys. These major divisions are in turn broken down into subdivisions, each of which is arranged chronologically. Name and geographical indexes serve as keys to the contents.-E.L.

\section{Social Sciences}

Miller, Elizabeth W. The Negro in America. Cambridge: Harvard Univ. Pr., 1966. 190p. $\$ 5$.

Topically arranged, with emphasis on social institutions and conditions, this useful work might be considered a kind of supplement to John P. Davis' recently published American Negro Reference Book. It is a selective guide to references on an important phase of American race relations, coverage being concentrated on articles published from 1954 through 1965. Each major section of the work commences with scope notes; some entries are annotated; and an author index concludes the volume. This significant bibliography brings up to date older ones in the field, and future editions will be welcomed.-M.G.

\section{Poverty and Human Resources Abstracts.} v.1, no.1- , Jan./Feb. 1966- . Ann Arbor: Institute of Labor and Industrial Relations, 1966- . Bi-monthly. \$30 yr.

Concerned with poverty, human reources and manpower development, this service provides information on research and action programs, policy trends, and heir progress. Although there is emphasis n US activities, primary and secondary ources are international in scope, and pver three hundred and fifty publications re regularly scanned for relevant material. Appearing bi-monthly, the form has been nade flexible to allow for changing needs, ind arrangement varies from issue to issue. Besides the major section of abstracts with ubject and content analyses, features inlude reports on national and state legisla- tion, working papers, reprints of articles, subject bibliographies, and a section of citations for which a brief annotation rather than a full abstract is provided. An index appears for the abstracts only; one for the annotated items would be welcome. The need for this publication is undeniable and, once better organized, it will be of great value.-M.G.

Wynar, Lubomyr Roman. Guide to Reference Materials in Political Science; a Selective Bibliography. Denver: Colorado Bibliographic Institute, 1966- . v.1- . (v.l, \$6.50)

The Guide is intended to introduce the student and the librarian to the reference tools of political science and related disciplines. This first volume is devoted to general reference sources in social and political science, plus sections on political theory and ideology. (A second volume is to cover public administration, political parties, public law, international relations, and government documents.) Very brief, descriptive annotations are provided for most titles; the more general reference works are treated at greatest length. There is an author index, but unfortunately the broad subject arrangement is not supported by a detailed alphabetical subject index. This seems a considerable limitation on the usefulness of the guide, although the author expresses hope that the rather full table of contents will compensate.-L.B.

\section{Dictionaries}

Grimm, Jakob and Grimm, Wilhelm. Deutsches Wörterbuch. Neubearbeitung, hrsg. von der Deutschen Akademie der Wissenschaften zu Berlin in Zusammenarbeit mit der Akademie der Wissenschaften zu Göttingen. Leipzig: S. Hirzel Verlag, 1965- . Bd.1-

Contents: Hinweise; Bd.1, Lfg.1, A-Abenteuer.

Memories of the problems of assembling and binding all the parts of the first edition (1854-1960; Guide M241, etc.) of this great work must not deter librarians from welcoming the beginning of a new edition. Work is proceeding jointly at the Berlin and Göttingen academies, and one hopes that the parts will appear in alphabetical 
sequence. In addition to continuing the scholarly tradition of the earlier edition, and the obvious advantages of incorporating new research, the second edition offers a slightly larger page and considerably more readable typography.-E.S.

The Random House Dictionary of the English Language. New York: Random House, [1966]. 2059p. il., maps. \$25.

Indications are that this dictionary will be almost as widely (if, perhaps, less controversially) reviewed as was "Webster 3." Although a new work, it bears a distinct "family resemblance" to the American College Dictionary, using the same type-face and type-size, and incorporating various features of the smaller work: keys to etymology and pronunciation at the foot of the pages; personal and place names, titles of literary works, foreign words and phrases all included in the main body of the work, etc. Examples of usage are frequently given in $R H D$, but are not identified as being drawn from published sources. For libraries, up-to-dateness of vocabulary will be the real virtue of the work, but its relative inclusiveness and encyclopedic features (plus the atlas section, chronology, etc., which are superfluous in any but the smallest library) will have appeal for home purchase. -E.S.

\section{SCIENCE}

European Research Index; a Guide to Scientific and Industrial Research in Western Europe. Guernsey, Channel Islands: F. Hodgson Ltd., 1965. 2v. (1694p.) $£ 22,10$ s.

This directory "contains the first comprehensive lists of research establishments in many countries and covers the research facilities of European industrial firms for the first time." (Publishers' Introd.) After a general section listing European agencies, arrangement is alphabetic by country for the nineteen West European countries included. Within each country two alphabetic lists appear: first, research centers, firms, laboratories; and second, universities. For each entry are given title, English translation (except for industrial firms), address, director of research and subject of research conducted or promoted. Each section is prefaced by a short essay on the organiza- tion of research in the country, with useful citations to two or three "further readings" on the subject. Two indexes-original language titles, and English equivalents-are found in volume two.-R.K.

\section{LITERATURE}

Akademiia nauk SSSR. Fundamental'naia biblioteka obshchestvennykh nauk. Sovetskoe literaturovedenie $i$ kritika: Russkaia sovetskaia literatura (obshchie raboty); knigi $i$ stat'i 1917-1962 godov. Bibliograficheskii ukazatel'. Moskva: Nauka, 1966. 586p. 3r.,12k.

This is a bibliography of Russian literary history and criticism on the general aspects of Soviet literature; individual authors will be covered in a separate volume. Annotated entries based on personal inspection of the materials are given for monographs, essays in collections, articles of research and criticism, the prefaces and epilogues of books, reviews, published documents, memoirs, speeches, and bibliographies. Arrangement is classified, and there is a detailed index.E.L.

Campbell, Oscar James, ed. The Reader's Encyclopedia of Shakespeare. New York: Crowell, [1966]. 1014p. \$15.

Arranged in dictionary form, this single volume provides essential information on Shakespeare, his life and work, in a concise and highly readable manner. An all-embracing view of Shakespearean criticism is presented from his own time to the present, with even a section on computer scholarship. Entries for literany influences, forms, characters, trends, critics and historians, Shakespeare's contemporaries, festivals, and interpreters are included. Several articles are done in essay style and are signed with initials of noted scholars in the field. Entries for Shakespeare's individual works contain notes on the text, date, sources, stage history, and plot synopsis, plus critical comments, a bibliography of outstanding editions and critical writings, and selected quotations from various writers, with sources given. Numerous illustrations are included; cross-references are provided; and a selected bibliography rounds out this very useful contribution to Shakespeare studies.-M.G. 
Dizionario enciclopedico della letteratura italiana. Direttore: Giuseppe Petronio. Laterza: UNEDI, 1966- . v.1Contents: v.1, A-Ca.

When completed in six volumes, this ambitious dictionary will be one of the major keys to a great literature. Modelled somewhat on Bompiani's work of world-wide scope (Guide R31), this set is restricted to the literature of one country and language. The first and largest section of the dictionary, comprising volumes $1-5$, is to be a listing in one alphabet of major and minor Italian authors together with classical and foreign authors who have influenced Italian letters; politicians, princes, and popes who have patronized the literature; movements, cultural institutions, libraries, journals and magazines, and the language and terms of literary criticism. Author entries are composed of an expository or critical text followed by two bibliographies: a list of the definitive editions of the writer's work, and a list of books and articles about his work. A second section will be a title listing of all works cited in the articles, and will serve as a quick means of identifying the authors. Finally, the editors plan a third section as a general index. Here it will be possible to locate all references in the dictionary to a given author-his works, adaptations of works, his imitators and critics, his themes-indeed, everything that will help to build around the central article a more complete picture of the man and his influence. The handsome volumes are printed on good paper and illustrated in black and white.-H.M.

Fisher, John H., gen.ed. The Medieval Literature of Western Europe; A Review of Research, Mainly 1930-1960. New York: New York Univ. Pr. for the Modern Language Association, 1966. 432p. \$6.50.

Like other useful MLA "review of reearch" volumes, this book contains authoriative surveys of scholarship, each written py a specialist. Chapters cover Latin, Old nd Middle English, French, German, Old Norse, Italian, Spanish, Catalan, Portufuese, and Celtic medieval literatures. The ssays do not discuss primary works, nor lo they pretend to cover all the scholarhip in each language, but confine them- selves to a "discussion of the tools for research and the most important research produced between about 1930 and 1960," with the purpose of putting "into the hands of advanced graduate students and younger scholars ... dependable evaluations of the research in medieval literature." (Foreword) An explanatory table of abbreviations used and an index of proper names are included.-R.K.

Harvard University. Library. Twentieth Century Russian Literature. Cambridge: Harvard Univ. Pr., 1965. 142, 139, 140p. $\$ 20$. (Widener Library Shelflist, no. 3)

One of the first results of the Harvard library's experimentation in computer applications is the publication of three computer-produced portions of the Widener shelflist. Earlier issues dealt with the crusades and Africa. The present work covers the writings of twentieth century Russian literary authors, both Soviet and emigré. Only that section covering books by and about individual authors is included. There are three arrangements of the book's contents: by call number, by author, by date. Entry gives surname with initials, title, place and date. Typeface is "computer" upper case-small, but well-spaced and easy to read-and entries are rarely longer than one line. Updated editions and supplements are planned, and other portions of the shelflist are to be published.-R.K.

Watters, Reginald Eyre and Bell, Inglis Freeman. On Canadian Literature, 18061960; a Check List of Articles, Books, and Theses on English-Canadian Literature, Its Authors, and Language. ${ }_{\text {[T }}$ Toronto $_{1}$ : Univ. of Toronto Pr., 1966. 165p. $\$ 7.50$.

Arranged by broad subject areas, with a separate section for individual authors, this bibliography presents a comprehensive introduction to Canadian literature in English, bringing together widely scattered articles both on the state of the national literature and on its practitioners. Items are included, as stated, from 1806 through 1960 , though most of the articles are from relatively recent years. The aim of the authors is to facilitate the study of the national literature, especially belles lettres. Given this specific goal, it seems regret- 
table that they decided to omit all study of the flourishing French Canadian school and, except for such few items as turn up in the "general" section, the effect on a national literature of two strong languages. Within the stated scope, however, this is a useful point of departure in a field not well served by bibliographic aids, and it is a valuable and necessary companion to C. F. Klinck's Literary History of Canada (Toronto, 1965) which is also limited to Canadian literature in English.-B.R.

\section{BIOGRAPHY}

American Men of Science; a Biographical Directory. The Physical and Biological Sciences. 11th ed. Supplement 1- . New York: Bowker, 1966- . \$10-\$20 per v.

In order to help satisfy the demand for current information while avoiding the need for publishing new editions more frequently, Bowker is offering this new series of supplements to its biographical directory for the physical and biological sciences. To be used in conjunction with the base volumes of the still incomplete eleventh edition, the supplements will be published in a cumulative pattern (e.g., the first covers A-C; the second will cover A-G, etc.) and will include complete new biographies (1150 in Supplement 1), plus important new data such as changes in position, deceased notices, etc., for biographees in the main set. Criteria for inclusion are as for the base volumes. Four supplements are planned for the physical and biological sciences section; the last, covering through $\mathrm{Z}$ is scheduled for late 1967-presumably very soon after publication of the final volume of the main set for this area.-E.S.

Talbot, C. H. and Hammond, E. A. The

Medical Practitioners in Medieval Eng-

land; a Biographical Register. London:

Wellcome Historical Medical Library, 1965. 503p. $84 s$.

"To bring together in convenient form all discoverable biographical information on the members of the medical profession in medieval Britain" (Introd.), the authors of this unusual register searched all major collections of printed source material of British medieval history, pertinent manuscript collections, Public Record Office documents, and local historical society publications.
The result is a compilation of thoroughly documented biographies (each statement is carefully footnoted) from the earliest times to 1518. Arrangement is alphabetic by forename, with dates so far as known. Entries range in length from mere identification to thousand-word articles. The work is of value not only to the historian of medicine, but to anyone interested in medieval British culture. A list of books consulted, of abbreviations used, and a full index of names, places, and subjects enhance the book's reference worth.-R.K.

U.S. Library of Congress. Hispanic Foundation. National Directory of Latin Americanists; Biobibliographies of 1,884 Specialists in the Social Sciences and Humanities. Washington, Library of Congress, 1966. 351p. \$2. (Its Hispanic Foundation bibliographical series, 10)

This welcome directory of contemporary scholars resident in the United States is designed to provide reliable information on clearly specialized professional personnel in Latin American studies, and by doing so, to encourage communication among scholars of related interests. Two groups are included in this selected list: "area" specialists, and those whose fields (e.g., economics, political science) are not limited by geography but "whose personal interest and linguistic abilities would make it feasible and desirable for them to undertake professional pursuits in Latin America." (Introd.) Entries, arranged alphabetically by name, give place and date of birth, major discipline, degrees, career, honors, research specialities, major publications, language knowledge, linguistic studies, and address.-R.K.

\section{History}

Chung, Yong Sun. Publications on Korea in the Era of Political Revolutions, 1959. 1963; a Selected Bibliography. [Kalama. zoo, Mich.]: Korea Research and Publica tion, Inc., [1965]. 117p. $\$ 3.50$.

A classified list of 967 titles in Korean Chinese, Japanese, and Western languages this is a companion to K. P. Yang's Refer ence Guide to Korean Materials, 1945-195s and to S. H. Lee's Korea; $a$ Selected Bibli ography in Western Languages, 1950-1958 Most of the titles listed are in the Korean 
unit of the Library of Congress, and are of South Korean origin, but enough North Korean materials are meant to be included to answer basic reference needs. While the work includes government publications, professional and academic periodicals, as well as books, it is not intended to be exhaustive; it seeks merely to "provide basic information necessary for study of the present political, economic and social life of Korea." (Introd.) Reference use is facilitated by separate author and title indexes and the standard romanization of alphabets throughout.-C.S.

France. Comité français des sciences historiques. La recherche historique en France de 1940 à 1965. Paris: Editions du Centre National de la Recherche Scientifique, 1965. 518p. 40F.

This work is primarily a research guide to French historiography and, as such, it begins with two long essays: one on French historiography itself, and the second on historical research and the teaching of hisory in France. These are followed by a section which describes those institutionschools, archives, libraries, museums, and esearch institutes-which are centers for historical scholarship in France; and a secion on publications (including a descripion of the types of theses required in France), with an annotated list of French pistorical journals. The last half of the volime is devoted to a bibliography of hisorical monographs published by French historians from 1940 to 1964 .-E.L.

pkinshevich, Leo. Latin America in Soviet Writings; a Bibliography. Robert G. Carlton, ed. Baltimore: Johns Hopkins Press for the Library of Congress, $\left.{ }_{[} 1966\right]$. $2 \mathrm{v}$. $\$ 15$ ea.; $\$ 25$ the set.

Contents: v.1, 1917-1958; v.2, 19591964.

These two volumes supersede and exand the bibliography by Leo Okinshevich nd Cecilia Gorokhoff (Suppl. 4V150) isued by the Library of Congress in 1959 inder the same title. The work now inludes a total of 8,688 entries, topically aranged. Citations are given in transliteraion, together with an English translation f the title. The bibliography covers writngs in Russian and other languages of the
Soviet Union on the "geographical and cultural area" of Latin America, and the works of Latin American authors translated into Russian. Subject matter includes not only politics, but literature and the fine arts as well, thus conveniently bringing together a wide range of material in one source. -B.R.

Pearson, James Douglas. Oriental and Asian Bibliography; an Introduction with Some Reference to Africa. Hamden, Conn.: Archon Books, 1966. 261p. \$7.50.

Mr. Pearson's guide is not an extensive bibliography of Asian bibliographies, but rather an introduction to Oriental and Asian bibliography as a whole. It is thus divided into three main sections dealing with (1) the producers of the bibliographies; (2) the bibliographic controls (both in indigenous and European languages); and (3) the libraries housing outstanding collections on these areas. Only ninety pages are devoted to a discussion of the bibliographic tools themselves. The reference works and periodicals included deal mainly with the whole Asian continent; area studies are, for the most part, omitted. The work is intended for the librarian or library student in need of a general guide to Oriental bibliography; it is not suited to the needs of the intensive researcher in the field. There are author and subject indexes.-L.B.

Wilber, Donald Newton, ed. The Nations of Asia. New York: Hart, [1966 ${ } .605 p$. il. $\$ 15$.

This is a collection of surveys of twentyfour Asian areas (excluding Asian parts of the Soviet Union) arranged alphabetically. Background essays written by specialists are followed by sections giving general factual and statistical information on political, economic, social and cultural conditions of the individual countries. There are numerous illustrations and maps, and a reprint of a Time magazine article on discrimination and discord in Asia serves as a fairly objective introduction to the whole volume. Most of the information, however, can be readily found in encyclopedias and yearbooks, and it is questionable whether the advantage of having it brought together in this volume altogether justifies the price.C.S. 


\section{The information he needs is in another library 2000 miles away. But he'll have it in a few minutes.}

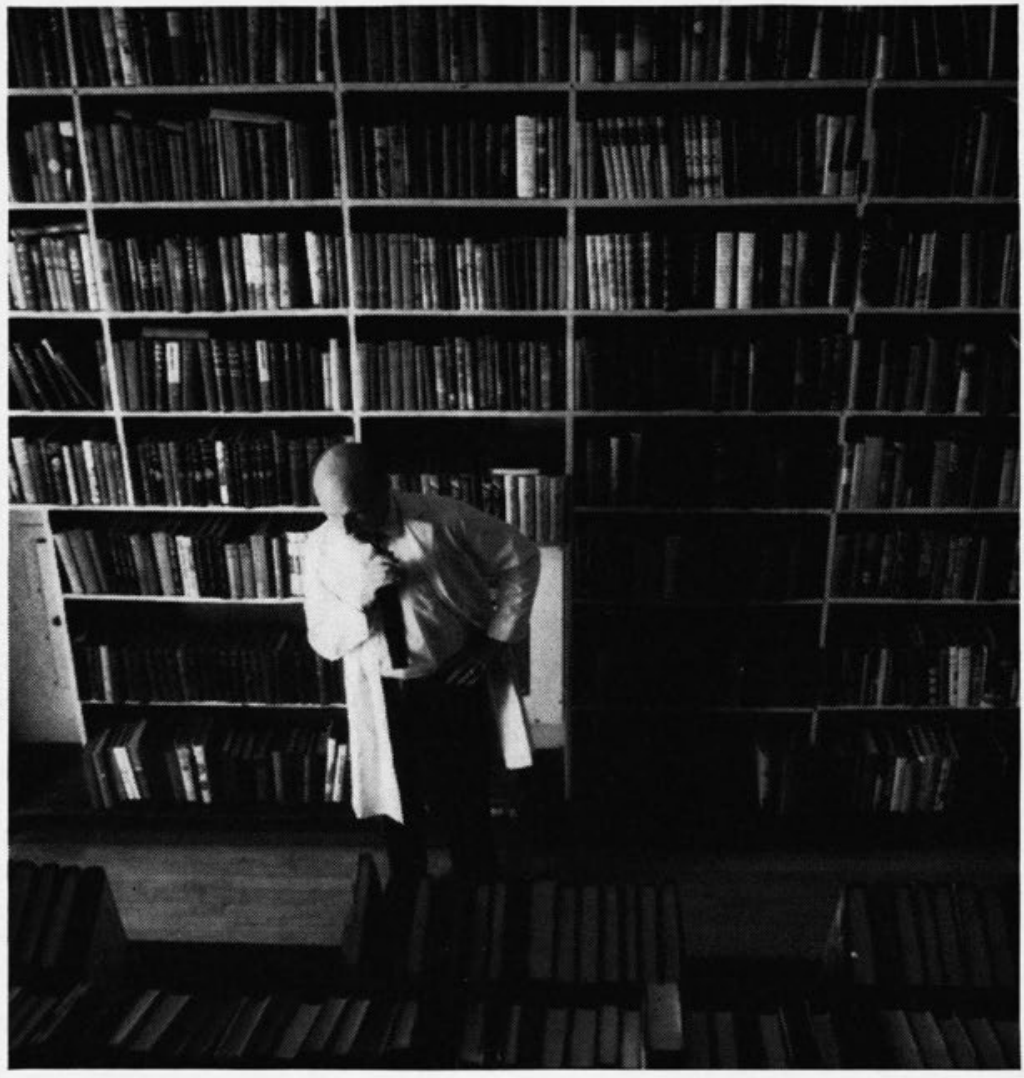

Even the University of Virginia library, one of the major depositories of knowledge in the United States, doesn't have everything. But it has supplemented its resources materially by the use of teletypewriter service.

Now, when a firm or individual needs information from a book or journal, the request can be sent to the library which most likely has it. The required information can be sent back in a few minutes.
All major universities and researcl centers in Virginia are linked by teletype writer. Any library in the United State with teletypewriter exchange service ca contact any other similarly equippe library to send or receive information.

To learn more about how Bell Systen facilities can expand your library facili ties, contact our Communications Con sultant in the field of education. He's specialist and knows your problems.

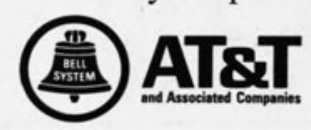

